\title{
Some approaches to translation of professional terms abbreviation in materials science
}

\author{
Natalya Sigacheva ${ }^{1 *}$ [0000-0002-8746-6828], Khanif Makayev ${ }^{1}$ [0000-0001-6953-2329], Guzal Makayeva² \\ [0000-0002-8656-328X], and Diliara Gainanova ${ }^{2}$ [0000-0001-6811-0853] \\ ${ }^{1}$ Kazan (Volga Region) Federal University, 420008, Kremlyovskaya st., Kazan, Russia \\ ${ }^{2}$ Kazan State University of Architecture and Engineering, 420043, Zelenaya st., Kazan, Russia
}

\begin{abstract}
The dynamic growth of international collaboration in the scientific and professional spheres leads to a wave-like increase in the volume of translations of professional and scientific texts and determines the relevance of the problem under study. Translators have problems translating abbreviations of professional terms. This paper analyzes the ways of translating English abbreviations in the field of materials science. As research methods, we used, among other things, the analysis of methods of translating English abbreviations into Russian, the study of articles in the field of materials science, the collection of data on abbreviations of professional terms and the comparison of the ways of translation of abbreviations of professional terms in the texts of materials science. The article reveals the features of the ways of translating abbreviations of professional terms in materials science texts. The main results of the research work are the identification of problems of translation of English abbreviations that the translator faces in the field of materials science, and the determination of the use frequency of one or another translation method. The materials of the article can be useful for researchers in this field, physics students and translators of scientific and technical texts.
\end{abstract}

Keywords: English, translation, abbreviations, professional terms, Materials science.

\section{Introduction}

Development of science and technology leads to the growth of new terms and concepts the translation of which requires a high level of skills from translators. English is the most common language of international collaboration in professional and scientific spheres. The number of scientific and professional projects carried out in cooperation with partners from different countries is also growing rapidly. The large volume of text material, the limited time frame, and the specifics of translating texts related to a particular field of activity cause problems even for experienced translators. Translators have problems with specifics of professional terms translation, such as translation of professional terms abbreviation.

\footnotetext{
*Corresponding author: nsigacheva@mail.ru
} 
Thus, the correct translation of terms becomes an urgent problem that requires both theoretical research and practical analysis of the use of various translation methods.

Except ensuring professional skills, translation process provides language learners with the development of their thinking abilities as well. The main thing here is to emphasize the teaching methods not on the amount of knowledge, but on the need to learn all your life, i.e. to teach not to think, but to think. One of the many opportunities for the development of students' thinking is, in our opinion, translation as one of the components of their foreign language training. Translation is a very ancient type of human activity that performs an important social function, which makes possible interlingual communication of people, but only in the twentieth century man has come to realize its importance and special place in the process of education.

Along with a large number of important functions of translation, such as, for example, overcoming linguistic and cultural barriers, the formation of national cultures, translation, according to scientists, is also a means of developing thinking. When translating, we deal with at least two languages. Since ancient times, language has been actively involved in thinking processes. If in the beginning there were only two types of thinking - practicaleffective and visual-figurative, then gradually a new, qualitatively higher type of verballogical thinking arose. Due to this, the development of thinking in general was stimulated. The emergence and development of writing intensified the impact of language on thinking. As L. S. Vygotsky stated «... language is a means not to express a ready-made thought, but to create it ... it is not a reflection of the existing worldview, but the activity that composes it» $[1$ p.212].

The problems of translation of professional terms arouse the interest of many Russian linguists. M. Yu. Krapivina and A. S. Fomichenko identify features of single-component and multicomponent terms [2]. M. A. Khlybova explores the main details of professional translation and lists recommendations for correct interpretation of texts [3]. L. R. Sakaeva analyzes translation features of author neologisms [4]. Translation of «false friends of a translator» as an interlingua phenomenon was considered in $[5,6]$. Some language difficulties for translation authentic professionally-oriented texts on construction were considered in [7].

Professional terms have been studied by many foreign scientists. H. Andreas explains the principle distinction between observational and theoretical terms, considers possible critical comments and additions to this distinction [8]. M. Ali and Z. Ismail study comprehension level of common non-technical terms in science [9]. S. Vakulenko analyzes and generalizes different views on term and terminology [10]. The ways of forming of professional lexical units in different fields of Physics from the point of view of their structure and semantics and their influence on the increase of common language vocabulary is considered in [11]. The fact of emerging of new professional terms and their transition to the stratum of commonly-used words has been studied in [12]. Use of digital technologies in translating of various scientific texts from English into Russian was considered in [13].

Most of professional terms are expressed using phrases or complex words. A trend of saving word building and improving word form is very popular. It leads to using abbreviations. Abbreviations is an important component of professional terms, and plays a key role in reducing the time of writing scientific work and make it easier to understand for reader.

Translation of professional terms abbreviation from English to Russian in scientific texts of such fields as Materials science has some special difficulties. Practical analysis showed that the main problem in the process of professional translation of abbreviations is the need to combine knowledge of a foreign language and a certain field of science. The specifics of abbreviation term translation from English to Russian are explored by E. V. Pavlova and T. G. Lapteva [14]. I. A. Ulitkin and L .L. Nelubin investigate using and 
translation of abbreviations in scientific and technical texts [15]. However, abbreviations of professional terms in the sphere of Materials science are not sufficiently studied. The purpose of this article is to analyse methods of translation English abbreviations in the sphere of materials science.

\section{Methods}

For a deep and versatile consideration of the research problem, the following methods of scientific search were used: a comparative analysis of authentic scientific and professional texts, generalizations and systematization of scientific works, processing of the data obtained. The scientific works of such scientists as M. Yu. Krapivina, L. Fomichenko [2], M. A. Khlybova [3], L. R. Sakaeva [4] and well-known foreign scholars such as M. Ali and Z. Ismail [9], H. Andreas [8] represent the basis of the research. The main approach of the research is based on are the comparison, observation and empirical methods. Essential information was got from authentic professional journals. The comparison method ensures taking into account the similarities and differences between terms translation. Through the observation method we analyzed literature, as well as dictionaries, and find out the similarities and differences of the meanings of the terms in the English and Russian languages. The methods allow overcoming translation problems of the terms of the target and origin languages that are used in several meanings.

\section{Results}

In the course of the research, original articles published in Acta Materialia which is a scientific journal of the Elsevier Science Publishing Company were studied. The journal publishes full-length original articles and reviews in the field of processing, research of the structure and properties of inorganic materials. Translators (teachers and undergraduates of Kazan Federal University) took part in the research and analysis of the results obtained.

The abbreviation translation in equivalent Russian abbreviation is used in case when it is available in Russian. Usually this method is practiced if such an abbreviation is firmly accepted. There are two approaches of foreign abbreviation translation using this method. The first of them is that translation of abbreviation is built in the same way as it is built in a foreign language. For example, TEM (Transmission electron microscopy) - PEM (Prosvechivayushchaya elektronnaya mikroskopiya). The second way is UPS (Ultraviolet photoelectron spectroscopy) - UFES, (Ul'trafioletovaya fotoelektronnaya spektroskopiya)), Rpm (revolution per minute) - ob/min (oborotov $v$ minutu).

Foreign abbreviation borrowings with Latin spelling are used in case if abbreviations don't have any difference in word building and lexical meaning. It is very uncommonly way of translation and it is primarily used for transmission of abbreviations included in any system of conventions: unit of measurement ${ }^{\circ} \mathrm{C}$ (Celsius degree) - ${ }^{\circ} \mathrm{C}$ (gradus Cel'siya), title of program Dtree (decision tree model) - Dtree (Model' drevo reshenij), Matlab (Matrix Laboratory) - Matlab (Matrichnaya laboratoriya).

Recently the number of English scientific terms abbreviations transferred to Russian without translation is increased steadily. Titles of various institutions, theories, names of the scientists, who made the discoveries are transliterated. Thus, using transliteration the abbreviations of the following terms are transferred: DFT (density functional theory) - TFP (Teoriya funkcionala plotnosti), BET method (Brunauer-Emmett-Teller method) - Metod BET (Metod Brunauera-Emmetta-Tellera).

The transcription of the English abbreviations is used in cases when these abbreviations represent the name of a company and institute which don't have a relative form in Russian. 
This method is quite relevant for translating abbreviations of scientific terms and has increasing growth of cooperation with foreign laboratories and companies. A good example of transliteration are names of scientific journals Phys. Rev. (Physical Review) - Fiz. Rev. (Fizikal Rev'yu).

The following way of translation abbreviation of scientific texts is descriptive translation. It is generally accepted to define descriptive translation as a transformation of the lexical and grammatical structure, whereby the lexical unit in the original language is replaced by a phrase that explains its meaning, and thus suggests more or a less complete explanation of this meaning in the target language. This method is used when there is no equivalent translation abbreviation in Russian. As an example, we can consider such terms translation: Coil gradient - Perepad temperatury mezhdu katushkoy i okruzhayushchim maslom; Hydraulic water - Voda, postupayushchaya v gidravlicheskiy klassifikator. Widespread abbreviation in English as ML (Machine Learning) which doesn't have equivalent in Russian and can be translated as Mashinnoe obuchenie, and another one HEAs (high entropy alloys) can be translated as Vysokoentropijnye splavy.

Another way to translate an abbreviation from English into Russian is to create a new abbreviation based on the translation according to the rules for creating a Russian abbreviation:

Lda (linear discriminant analysis) - Lda (Linejnyj diskriminantnyj analiz).

The results of quantitative analysis are shown in Fig. 1.

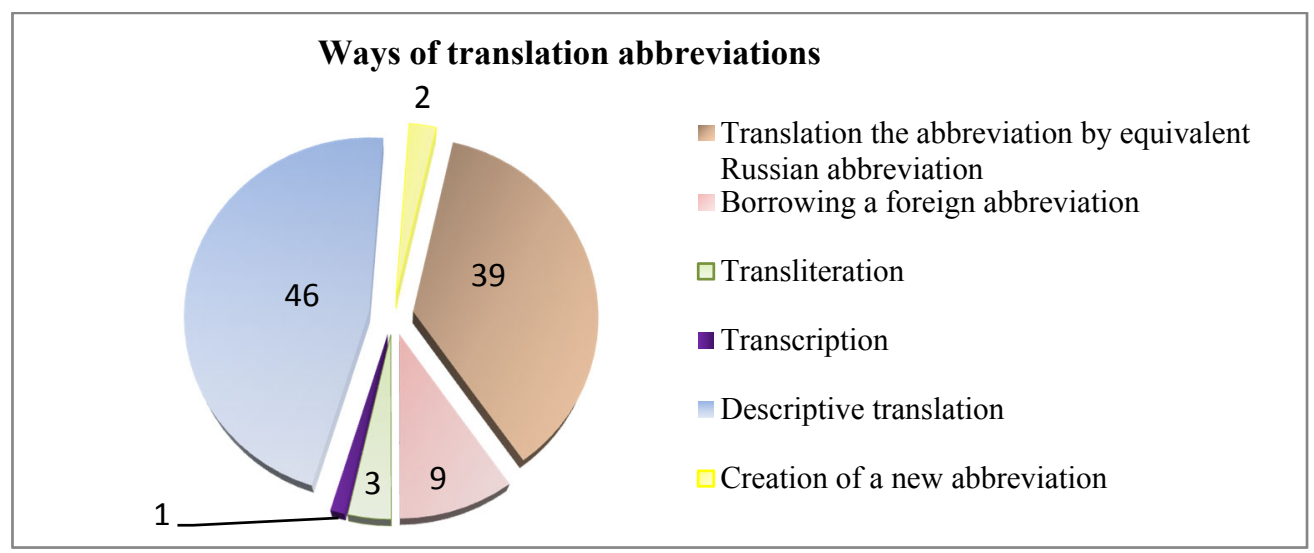

Fig. 1. Ways of translation abbreviations.

The diagram clearly demonstrates the frequency of using methods for translating abbreviations of professional terms in materials science articles. Most of the abbreviations have been translated using a descriptive method - $46 \%$, slightly less - $39 \%$ of terms have been translated using the equivalent Russian abbreviation. Relatively rarely, translators use borrowings of a foreign abbreviation - $9 \%$. About $3 \%$ of abbreviations have been translated using transliteration. This is somewhat more than a way of creating a new abbreviation, which is used only in $2 \%$ of cases. Transcription is the least commonly used as a way of translating abbreviations - $1 \%$. Hence, the most common way to translate professional terms in materials science is descriptive translation.

\section{Discussion}

Linguists researching methods acronym translation within the framework of a business letter suggest using the following ways of translation of abbreviations from English to 
Russian: translation of an abbreviation in the equivalent of a Russian abbreviation; borrowing as a translation of a foreign abbreviation; transliteration; transcription; descriptive translation [16]. Scientists emphasize that the translation of an abbreviation into an equivalent Russian abbreviation assumes its presence in the language. The absence of such an equivalent, according to the scientist, suggests the creation of a new Russian abbreviation as an additional method [17]. In this study, we consider it possible to agree with the classification of methods for translating abbreviations proposed by L. L. Ulitkin and L. L. Nelyubin [15], in which the scientists indicate the following methods: translation of the full form and creation Russian abbreviations; translation of the full form; transliteration; English abbreviations borrowing; transcription; sound-letter transcription; translation and transcription. A comparative analysis of the translation of professional and scientific texts has shown that translators most often use these methods of translating abbreviations. Proper educating the future construction specialists to the use of the lexical units under consideration correctly can improve their professional growth.

The difficulty, which is caused by such a feature of a technical text as a high degree of information density, is the presence of a large number of abbreviations and abbreviations, when translating which it is necessary either to find a generally accepted abbreviation in Russian, or translate with a descriptive translation, or give a decryption in a footnote, or leave an English abbreviation. The latter method is possible, provided that it is known that the recipient has the necessary background knowledge.

In more complex cases, a genitive translation model is used, i.e. the defining noun is translated by a post-positive noun in the genitive case: file and image formats - «форматы файлов и изображений», special software packages - «пакет программных приложений», command line program - «программа командной строки». Sometimes during translation, it may be necessary to rearrange the components of the term: virtual storage slots - «виртуальные устройства хранения», Open Virtualization Format «формат открытой виртуализации». Sometimes in translation it is necessary to add a preposition: disaster recovery - «восстановление после сбоев», Intel or AMD-based computers - «компьютеры на системе Intel или AMD». All these approaches should be taken into consideration while translating abbreviations in professional texts.

Achievement of adequacy in translation is associated with the ability to correctly identify the translation problem and carry out the necessary translation transformations that occur due to incomplete generality or differences between the source and translated texts.

\section{Conclusions}

The rapid development of international engagement in science is necessitating professional terms translation. The translations of specific professional terms such as abbreviations cause difficulties for translators. The most common ways of translation abbreviations professional terms in the sphere of Material science were researched. Quantitative analysis and comparison of methods showed that the most widely used way of translation abbreviation of professional terms in Material science is descriptive translation.

The main types of errors while translating are:

- representing a gross distortion of the content; as a result, the translation points to a completely different situation and actually misinforms the receptor;

- leading to inaccurate transmission of the meaning of the original, but not distorting it completely - the translation describes the same situation as in the original, but its individual details are not indicated accurately enough;

- not violating the general meaning of the original, but reducing the quality of the translation text due to deviations from the stylistic norms of the translating language, 
the use of units that are of little use in this type of text, abuse of foreign language borrowings or technical jargon;

- violations of the mandatory norms of the target language, which do not affect the equivalence of the translation, but testify to the translator's insufficient proficiency in the given language or his inability to overcome the influence of the original language.

Scientific terminology is constantly having changes and requires introduction of new abbreviations. Thus, this problem needs further researches.

\section{References}

1. L. S. Vygotsky, Thinking and speaking, (Own. op. in 6 volumes, Pedagogy, Moscow, Rusia, 2, 1982)

2. M. Yu. Krapivina, A. S. Fomichenko, Specificity of translation of English terms in a professionally oriented text, Philological Sciences. Questions of theory and practice. 2, (2020) URL: cyberleninka.ru/article/n/spetsifika-perevoda-angliyskih-terminov-vprofessionalno-orientirovannom-tekste (Last accessed: 03/13/2021)

3. M.A. Khlybova, Features of the Russian-English translation of a scientific and technical article, Philological sciences. Questions of theory and practice. 11-2 (77), (2017) URL: hcyberleninka.ru/article/n/osobennosti-russko-angliyskogo-perevodanauchno-tehnicheskoy-stati (Last accessed: 03/13/2021)

4. L. R. Sakaeva, A. Yu. Ermolenko, M. A. Yahin, Translation features of author neologisms on the example of modern English prose, revista san gregorio, 23, 108-114 (2018)

5. Kh. F. Makayev, M. A. Yahin, G. Z. Makayeva, Interlingua Interferences in English and Russian in Physics Field, PROPOSITOS Y REPRESENTACIONES, 9, e1019 (2021)

6. Kh. Makayev. S. Takhtarova, M. Gulkanyan, and others, The urgency of considering "false friends of a translator" for construction specialists, IOP Conference Series: Materials Science and Engineering, 890,1 012205 (2020) DOI: 10.1088/1757899X/890/1/012205

7. N. A. Sigacheva, A. R. Baranova, Some language difficulties for translation authentic professionally-oriented texts on construction, IIOABJ Journal, 9, S2, 78-82 (2018)

8. H. Andreas, Theoretical Terms in Science, Stanford Encyclopedia of Philosophy, (2013) DOI: 10.1093/obo/9780195396577-0400

9. Ali Maznah, Ismail Zurida, Comprehension Level Of Non-Technical Terms In Science: Are We Ready For Science, In English. J. Pend. dan Pend., Jil. since 2010. 21. 73-83 (2006). URL: www.researchgate.net/publication/228841695_Comprehension_Level

10. Of_Non-Technical_Terms_In_Science_Are_We_Ready_For_Science_In_English (Last accessed: 09.09.20드)

11. M. Vakulenko, Term and terminology: basic approaches, definitions, and investigation methods (Easterm-European perspective), Terminology Science \& Research, 24, 13-28 (2014)

12. Kh. F. Makayev, A. R. Baranova, N. A. Sigacheva, Ways of vocabulary enlargement in the English sublanguage of Physics, Journal of Research and Applied Linguistics, 10 (SP), 793-801 (2019)

13. Kh. F. Makayev, L.R. Sakaeva, G.Z. Makayeva, and others, Word Building in the Sphere of Physics and its Influence on the Commonly-Used Vocabulary, in proccedings of the 5th International Multidisciplinary Scientific Conference on Social Sciences and Arts - SGEM 2018, 5, 3.6, 711-718 (2018)

14. N. A. Sigacheva, A. R. Baranova, Kh. F. Makayev, Digitization of Translation from English into Russian: Analysis and Comparison of Machine Service Quality, Applied 
Linguistics Research (ALR) Journal, 5(1), 130-136 (2021) DOI: 10.14744/alrj.2021.87699

15. E. V. Pavlova, T. G. Lapteva, Specificity of the transfer of terms of various types when translated from English into Russian, Interexpo Geo-Siberia, 2 (2014) URL: cyberleninka.ru/article/n/spetsifika-peredachi-terminov-razlichnyh-tipov-pri-perevodes-angliyskogo-yazyka-na-russkiy (Last accessed:: 03/13/2021)

16. I. A. Ulitkin, L. L. Nelyubin, Use and translation of abbreviations in a scientific and technical text, Science about man: humanitarian research, 4(18) (2014) URL: https://cyberleninka.ru/article/n/ispolzovanie-i-perevod-sokrascheniy-v-nauchnotehnicheskom-tekste (last accessed: 03/13/2021)

17. N. Sigacheva, A. Baranova, D. Vakhitova, M. Gulkanyan, D. Gainanova. Scientific communication and translation problems with synonyms, antonyms, homonyms in construction sphere, IOP Conference Series: Materials Science and Engineering, 890,1 012211 (2020) DOI: 10.1088/1757-899X/890/1/012211

18. M. Gallyamova, N. Klenovaya, Methods of acronym translation for within the framework of a business letter, Vestnik KGU im. N.A. Nekrasova, 2, 199-201 (2016) URL: cyberleninka.ru/article/n/priemy-perevoda-pri-rabote-s-abbreviaturami-v-ramkahdelovogo-pisma/viewer (Last accessed: 19.11.2020) 